Benha Veterinary Medical Journal
Official Journal Issued by
Faculty of
Veterinary Medicine Journal homepage: https://bvmj.journals.ekb.eg/

Original Paper

\title{
Enteropathogenic Escherichia coli contaminating chicken meat cuts
}

Shimaa, S. Sherif ${ }^{1}$, Saad, M. Saad ${ }^{1}$, Fatin, S. Hassanin ${ }^{1}$ and Marionett, Z. Nasif ${ }^{2}$

${ }^{I}$ Department of Food Hygiene and Control, Faculty of Veterinary Medicine, Benha University, Benha, Egypt

${ }^{2}$ Animal Health Research Institute "Benha branch", ARC, Egypt

\begin{tabular}{|c|c|}
\hline ARTICLE INFO & ABSTRACT \\
\hline $\begin{array}{l}\text { Keywords } \\
\text { Chicken cuts } \\
\text { Escherichia coli } \\
\text { stxgenes }\end{array}$ & $\begin{array}{l}\text { Although chicken meat cuts are of high nutritious, economic and consumers' demanded meats, } \\
\text { but it may be a serious microbial food poisoning cause referring to low hygienic procedures } \\
\text { during production. Therefore, the current study was established to isolate and identify } \\
\text { enteropathogenic Escherichia coli in one hundred random samples of raw chicken meat cuts } \\
\text { represented by chicken breast and thigh meat samples ( } 50 \text { of each) that were collected from } \\
\text { different poultry shops in Qalubiya Governorate. The obtained results revealed that the } \\
\text { incidence of } E \text {. coli was }(24 \%) \text { in all the examined samples, where it in thigh samples ( } 28 \%) \\
\text { were more than in breast ones }(20 \%) \text {. Serotyping of the isolated E. coli strains revealed that } \\
\text { they belonged to both enteropathogenic (EPEC) and enterotoxigenic E. coli (ETEC) serotypes. }\end{array}$ \\
\hline $\begin{array}{l}\text { Received } 19 / 04 / 2021 \\
\text { Accepted } 01 / 06 / 2021 \\
\text { Available On-Line } \\
01 / 10 / 2021\end{array}$ & $\begin{array}{l}\text { Moreover, out of six isolates that were molecularly investigated for Shiga toxins producing } \\
\text { genes, only one isolate revealed presence of Shiga toxin- } 2 \text { producing gene (stx-2) with } \\
\text { prevalence of } 16.67 \% \text {. So, it was concluded that, breast and thigh chicken meat cuts may harbor } \\
\text { pathogenic } E \text {. coli } \text { that possess public health hazards affecting consumers' health. }\end{array}$ \\
\hline
\end{tabular}

\section{INTRODUCTION}

Chicken trade has been progressively raised a magnificent development rate, that referred to that chicken meats have reliable reasonable prices, highly nutritious, rapid production cycle, and a flexible good sort of advancedprocessed products (Barbut, 2015).

Chicken meat cuts are continuously reported to be an incriminated common source of foodborne pathogens like salmonella spp. and E. coli (Yulistianiet al., 2019) which can be loaded to chicken meat across the production cycle beginning with scalding, defeathering and evisceration; also, cross contamination from contaminated close carcasses and equipment.

In addition, Mpundu et al. (2019) indicated that the importance of the used water sources in chicken carcass's dressing which represents a major source of high contamination levels. They found E. coli in $70 \%$ of the selected dressed chickens; where the number of total coliforms and E. coli were significantly higher in washed carcasses than pre-washed carcasses $(65$ and 35\%, respectively). Furthermore, intestinal contents may contaminate carcass's meat regarding to improper evisceration (Abd Elzaher et al., 2018).

The most of virulence genes of $E$. coli, especially Shiga toxins producing genes (stx-1 and st $x$-2), can infect consumers by consumption of the inadequately heat-treated contaminated meats causing significant troubles, including digestive, hematological, urinary, and respiratory affections (Makvanaand Krilov, 2015). Moreover, their presence in poultry meat and its products indicates lack of proper sanitation and possible fecal contamination (Nagi, 2020).
Also, Shiga-toxin producing E. coli (STEC) in patients especially young children develop watery diarrhea accompanied with abdominal pain (Brzuszkiewicz et al., 2011) and after which bloody diarrhea may appear within 24 days in about $80 \%$ of cases. In other cases, urinary tract infection, sepsis and other extra intestinal infections may occur (Griffin et al., 2012).

Other than E. coli $\mathrm{O}_{157}$ STEC strains, O26: $\mathrm{H}_{11} / \mathrm{H}^{-}$, $\mathrm{O}_{91}: \mathrm{H}_{21} / \mathrm{H}^{-}, \mathrm{O}_{103}: \mathrm{H}_{2}, \mathrm{O}_{111}: \mathrm{H}^{-}, \mathrm{O}_{113}: \mathrm{H}_{21}, \mathrm{O}_{121}: \mathrm{H}_{19}, \mathrm{O}_{128}: \mathrm{H}_{2} / \mathrm{H}^{-}$ , and $\mathrm{O}_{145}: \mathrm{H}_{28} / \mathrm{H}^{-}$were among the most common causes of foodborne and HUS diseases (Ursula et al., 2012).

Large outbreak with more than 800 hemolytic uremic syndrome (HUS) and 50 deaths in 2011 caused by STEC strains were reported (Tozzoliet al., 2014); this pathogenic E. coli cause diarrhea, hemorrhagic colitis (HC) and HUS as it has the capability of attaching and effacing (A/E) lesion to the enterocyte sharing with another $E$. coli group as enteroaggregative E. coli.

Therefore, the current study aimed to define the prevalence of enteropathogenic $E$. coli in chicken meat cuts.

\section{MATERIAL AND METHODS}

\subsection{Collection of samples:}

A total of 100 random samples of different raw chilled chicken meat cuts (breast and thigh) was collected from different chicken shops (50 of each), at Qalubiya Governorate, Egypt, for detection the prevalence of enteropathogenic E. coli strains in these samples, serotyping, and molecular typing of toxinogenic $E$. coli.

* Corresponding author: drshimaa137@gmail.com 


\subsection{Preparation of samples (ISO, 2017):}

Under complete aseptic condition, twenty-five grams of the examined meat samples with $225 \mathrm{ml} 0.1 \%$ sterile peptone water were aseptically mixed, and homogenized, then tenfold serial dilutions were prepared.

2.3. Enumeration and isolation of E. coli (ISO, 2001):

One $\mathrm{ml}$ from the previously prepared serial dilution was cultured in TBX agar by pour-plate technique and incubated at $44^{\circ} \mathrm{C} / 24 \mathrm{hrs}$. Suspected colonies (greenish to blue colonies) were counted and isolated for more identification. 2.4. Identification of E. coli isolates:

It was operated based on the morphological and biochemical characters as was reported by (MacFaddin, 2000); additionally, serological identification was performed according to Koket al. (1996).

\subsection{Statistical Analysis.}

the obtained results were statistically described using SPSS software according to Feldman et al. (2003).

2.6. Molecular detection of Shiga toxins 1 and 2 (stx-1 and $s t x-2)$ :

2.6.1. Oligonucleotide primers sequences were prepared according to Dipineto et al., 2006 as mentioned in Table (1). 2.6.2. DNA extraction, and amplification processes were performed following the commercial ready QIAamp DNA mini kit instructions.

\begin{tabular}{|c|c|c|c|}
\hline $\begin{array}{l}\text { Gen } \\
\text { e }\end{array}$ & $\begin{array}{l}\text { Primer sequence } \\
\left(5^{\prime}-3^{\prime}\right)\end{array}$ & $\begin{array}{l}\text { Length } \\
\text { of } \\
\text { amplifie } \\
\text { d } \\
\text { product }\end{array}$ & $\begin{array}{l}\text { Referenc } \\
\mathrm{e}\end{array}$ \\
\hline Stxl & $\begin{array}{l}\text { ACACTGGATGATCTCAGTGG } \\
\text { CTGAATCCCCCTCCATTATG }\end{array}$ & $614 \mathrm{bp}$ & \multirow{2}{*}{$\begin{array}{l}\text { Dipinetoe } \\
\text { t al., } 2006\end{array}$} \\
\hline Stx 2 & $\begin{array}{l}\text { CCATGACAACGGACAGCAGTT } \\
\text { CCTGTCAACTGAGCAGCACTTT } \\
\text { G }\end{array}$ & $779 \mathrm{bp}$ & \\
\hline
\end{tabular}

\section{RESULTS}

The bacteriological examinations of the examined chicken breast and thigh samples as mentioned in Table (2), revealed detection of $E$. coli in (24\%) of the total examined samples, which were considered rejected based on the Egyptian standards, where thigh samples were more contaminated than breast ones. In details, $10(20 \%)$ and $14(28 \%)$ of breast and thigh samples appeared to harbor E. coli, respectively.

Table 2 Statistical analytical results of E. coli count $(\log 10)$ in the examined fresh breast and thigh chicken samples $(\mathrm{n}=50$ for each

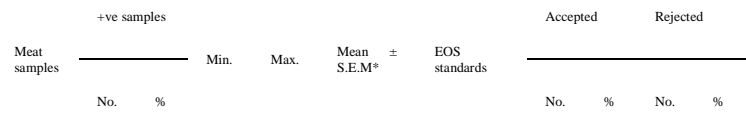

$$
\begin{aligned}
& \begin{array}{lllllllllll}
\text { Breast } & 10 & 20 & 3.00 & 5.14 & 4.21 \pm 0.01 & \text { Free } & 40 & 80 & 10 & 20
\end{array} \\
& \begin{array}{lllllllllll}
\text { Thigh } & 14 & 28 & 4.54 & 5.34 & 4.94 \pm 0.02 & \text { Free } & 36 & 72 & 14 & 28
\end{array} \\
& \begin{array}{lll}
\text { Total } & 24 & 24
\end{array}
\end{aligned}
$$

*S. E.M= Standard error of mean.

EOS legislation referring to the Egyptian standard no. (1651/2005). Escherichia coli isolates were serotyped which belonged to enteropathogenic (EPEC) as $\mathrm{O}_{55}: \mathrm{H}_{7}$ and $\mathrm{O}_{114}: \mathrm{H}_{21}$ serotypes with total incidence of 54.2 and $25.0 \%$, respectively, and enterotoxigenic E. coli (ETEC) as $\mathrm{O}_{125}: \mathrm{H}_{18}$ serotype with total incidence of $20.8 \%$, as mentioned in Table (3).

\begin{tabular}{|c|c|c|c|c|c|c|c|}
\hline \multirow{3}{*}{$\begin{array}{l}\text { E. coli } \\
\text { strains }\end{array}$} & \multicolumn{4}{|c|}{ Samples } & \multirow{2}{*}{\multicolumn{2}{|c|}{ Total }} & \multirow{3}{*}{$\begin{array}{l}\text { Strain } \\
\text { characteristic }\end{array}$} \\
\hline & \multicolumn{2}{|c|}{ Breast } & \multicolumn{2}{|c|}{ Thigh } & & & \\
\hline & No. & $\% *$ & No. & $\% *$ & & & \\
\hline $\mathrm{O}_{55}: \mathrm{H}_{7}$ & 5 & 50 & 8 & 57.1 & 13 & 54.2 & EPEC \\
\hline $\mathrm{O}_{114}: \mathrm{H}_{21}$ & 1 & 10 & 5 & 35.7 & 6 & 25.0 & EPEC \\
\hline $\mathrm{O}_{125}: \mathrm{H}_{18}$ & 4 & 40 & 1 & 7.14 & 5 & 20.8 & ETEC \\
\hline
\end{tabular}

Table 3 Serotyping of E. coli isolated from the examined fresh chicken meat samples $(n=24$ isolates $)$ E. coli

$\%^{*}$ : Incidence of E. coli serotypes in relation to number of isolates (10 for breast, 14 for thigh samples).

$\%$ **: Incidence of total $E$. coli serotypes in relation to total number of isolates (24).

Moreover, out of six isolates that were molecularly investigated for Shiga toxins producing genes, only one isolate revealed presence of Shiga toxin- 2 producing gene with prevalence of $16.67 \%$ as mentioned in Tables (4) and Fig. (1).

\begin{tabular}{|c|c|c|c|c|}
\hline \multirow{2}{*}{$\begin{array}{l}\text { E. coli } \\
\text { virulence } \\
\text { genes }\end{array}$} & \multicolumn{2}{|c|}{ stx 1} & \multicolumn{2}{|l|}{ stx 2} \\
\hline & No. & $\%$ & No. & $\%$ \\
\hline & 0 & 0 & 1 & 16.67 \\
\hline \multirow{2}{*}{ E. coli ID } & & \multicolumn{3}{|l|}{ Results } \\
\hline & & Stxl & Stx2 & \\
\hline 1 & & - & - & \\
\hline 2 & & - & - & \\
\hline 3 & & - & + & \\
\hline 4 & & - & - & \\
\hline 5 & & - & - & \\
\hline 6 & & - & - & \\
\hline
\end{tabular}

Table 4 Occurrence of virulence genes of Shiga toxin-producing E. col isolated from the examined samples of chicken cuts ( $n=6$ isolates)

STX2: Shiga- toxin 2 gene

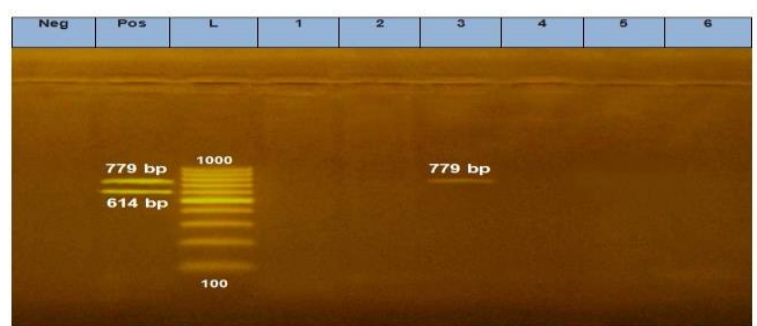

Figure 1 Agarose gel electrophoresis of multiplex PCR of stxl (614 bp), and stx2 (779 bp) virulence genes of Enteropathogenic E. coli. Lane L: 100 bp ladder as molecular size DNA marker. Lane Pos: Control positive E. coli for stx 1 , and stx 2 genes. Lane Neg: Control negative. Lane 3: Positive $E$. coli for stx2 gene, while negative for stx1.Lanes 1, 2, 4, 5, and 6: Negative $E$. coli for stx 1 and stx 2 genes.

\section{DISCUSSION}

Bacterial foodborne illness has been reported as international problem causing decline in economic growth (WHO, 2005), as the bacterial contamination of food with 
different foodborne pathogens and its multiplication, growth and/or toxin production has public health importance (Mensah et al., 2002).

Detection of various foodborne pathogens in fresh chicken meat cuts throw-lights on the poorly hygiene and personal conditions performed during different stages of slaughtering, storage, transportation and handling processes, such as contaminated water (Mpundu et al., 2019), intestinal contamination (Kamal, 2017), dusty air currents, sewage, and used equipment, and surrounding environmental surfaces (USFDA, 2012).

Escherichia coli is one of the most frequently isolated bacterial contaminations of chicken meat samples. So, referring to the documented results in Tables (1 to 4) and Fig. (1), they can be compared with the previously recorded results by Arakeeb (2020) (42.8\% and 62.5\% in breast and thigh samples, respectively); and Nagi (2020) who detected E. coli in 20 and $26.67 \%$ of the examined breast and thigh samples, respectively. Moreover, Elsabagh-Rasha (2010), Edris-Shima (2012), Hassanin et al. (2017), and Elsisy (2019) who recorded isolation of different $E$. coli serotypes included $\mathrm{O}_{55}: \mathrm{H}_{7}, \mathrm{O} 114: \mathrm{H} 21$, andO $\mathrm{O}_{125}: \mathrm{H}_{18}$ that belonged to EPEC and ETEC groups.

Furthermore, khattab (2020) and Nagi (2020) recorded detection of Shiga-toxin producing genes in their E. coli strains that were isolated from raw chicken meat cuts.

Variations between the current results and different authors may be referred to variations in sanitary and hygienic conditions of the collected samples, groceries variations, surrounded environment, and location of collection.

In addition, incidence of thigh contamination more than breast ones may be attributed to that the high fat content of thigh and the evisceration faults leading to fecal contamination which has been usually more prevalence in thigh than breast meats.

\section{CONCLUSION}

Finally, the obtained results proved that $E$. coli is a seriously, significant widespread foodborne bacterium, which represents public health hazards threatening meat safety and consumer's health. In addition, fresh thigh samples showed higher contamination rate with $E$. coli than breast samples with isolation of EPEC and ETEC strains from the examined samples. Therefore, addition of safe, hygienic sanitizers in washing water, followed by thorough cooking and hygienic handling is strongly recommended.

\section{REFERENCES}

1. Abd Elzaher, M., Saleh, E.A., Abd Elhamied, R., Talat, D. and Ibrahim, M.S., 2018. Studies on the prevalence of $E$. coli in chicken carcasses in abattoirs and its antibiotic sensitivity. Alex. J. Vet. Sci., 58(1): 132-138.

2. Arakeeb, S.M., 2020. Natural preservatives in raw chicken meat. Thesis, Master of Vet. Sci. (Meat Hygiene), Fac. Vet. Med., Benha Univ., Egypt.

3. Barbut, S. 2015. Microbiology and sanitation. In: The Science of Poultry and Meat Processing. University of Guelph, Guelph, Ontario, Canada, Ch. 2. Pp. 22-27.

4. Brzuszkiewicz, E., Thurmer, A., Schuldes, J., Leimbach, A. and Liesegang, H. 2011. Genome sequence analyses of two isolates from the recent Escherichia coli outbreak in Germany reveal the emergence of a new pathotype: Entero- Aggregative-
Haemorrhagic Escherichia coli (EAHEC). Arch. Microbiol., 193(12): 883-891.

5. Dipineto, L., Santaniello, A., Fontanella, M., Lagos, K., Fioretti, A. and Menna, L.F., 2006.Presence of Shiga toxin-producing Escherichia coli $\mathrm{O}_{157}: \mathrm{H}_{7}$ in living layer hens. Lett. Appl. Microbiol., 43: 293-295.

6. Edris-Shima, N., 2012. Detection of Enterobacteriaceae in meat and poultry cuts by using recent techniques. Thesis, Master of Vet. Sci. (Meat Hygiene), Fac. Vet. Med., Benha Univ., Egypt.

7. Elsabagh-Rasha, A., Saad, M.S., Edris, A.M. and Hassanin, F.S., 2010. Escherichia coli in meat and poultry product with special reference to identification of verotoxignic Escherichia coli using the PCR technique". Thesis, Master of Vet. Sci. (Meat Hygiene), Fac. Vet. Med., Benha Univ., Egypt.

8. Elsisy, S.E.A., 2019. Enterotoxigenic bacteria as potential hazards threaten the safety of some chilled meat, poultry and fish under the Egyptian marketing conditions. Thesis, Master of Vet. Sci. (Meat Hygiene), Fac. Vet. Med., Benha Univ., Egypt.

9. Feldman, D., Ganon, J., Haffman, R. and Simpson, J., 2003. The solution for data analysis and presentation graphicsll. 2nd Ed., Abacus Lancripts, Inc., Berkeley, USA.

10. Griffin, P., Manges, A. and Johnson, J. 2012. Foodborne origins of $E$. coli causing extra intestinal infections. Clinic. Infect. Dis., 55(5): 712-719.

11. Hassanin, F.S., Hassan, M.A., Shaltout, F.A., Abo Elroos, N.S. and Abd-Elhameed, G.A., 2017. Bacteriological criteria of chicken giblets. BVMJ, 33(2): 447-456.

12. ISO "International Organization for Standardization", 2001. No.16649-2. Microbiology of food and animal feeding stuffs-Horizontal method for the enumeration of glucuronidase-positive Escherichia coli - Part 2: colony-count technique at $44{ }^{\circ} \mathrm{C}$ using 5-bromo-4chloro-3-indolyl-D-glucuronide.

13. ISO "International Organization for Standardization", 2017. No.6887-2. Microbiology of the food chain Preparation of test samples, initial suspension and decimal dilutions for microbiological examination Part 2: Specific rules for the preparation of meat and meat products.

14. Kamal, A., 2017. Clostridium perfringens in meat and chicken received in university hostel. Thesis, Master of Vet. Sci. (Meat Hygiene), Fac. Vet. Med., Benha Univ., Egypt.

15. Khattab, R.S.A., 2020. Shiga toxin producing Escherichia coli in some chicken products. Thesis, Master of Veterinary Medicine (Meat Hygiene), Benha Univ., Egypt.

16. Kok, T., Worswich, D. and Gowans, E., 1996. Some serological techniques for microbial and viral infections". In: Practical Medical Microbiology (Collee, J.; Fraser, A.; Marmion, B. and Simmons, A., eds.), 14th ed., Edinburgh, Churchill Livingstone, UK. 
17. Macfaddin, J.F., 2000. Biochemical tests for identification medical bacteriall. Warery Press INC., Baltimore, Md. 21202 USA.

18. Makvana, S. and Krilov, L.R., 2015. Escherichia coli infections. Pediatrics in Review, 36(4): 167-171.

19. Mensah, P., Yeboah-Manu, D., Owusu-Darku, K. and Ablody, A., 2002. Street food in Accra, Ghana: how safe are they? Bulletin of the World Health Organization. 80: 546-556.

20. Mpundu, P., Munyeme, M., Zgambo, J., Mbewe, R.A. and Muma, J.B. 2019. Evaluation of bacterial contamination in dressed chickens at Lusaka abattoirs. Frontiers in public health, 7: 19-24.

21. Nagi, S.S., 2020. Virulence factors associated with food poisoning bacteria in chicken carcasses by multiplex PCR. Thesis, Ph.D. of Veterinary Medicine (Meat Hygiene), Benha Univ., Egypt.

22. Tozzoli, R., Grande, L., Michelacci, V., Ranieri, P. and Maugliani, A. 2014. Shiga toxin-converting phages and the emergence of new pathogenic Escherichia coli: a world in motion. Front. Cell. Infect. Microbiol., 20(4): 80-86.

23. Ursula, K., Herbet, H., Nicole, G., Lothar, B. and Roger, S. 2012. Human infections with non-O ${ }_{157}$ Shiga toxin-producing Escherichia coli. Emerg. Infect. Dis. J., (17): 2-9.

24. USFDA "U.S. Food and drug administration" 2012. Bad Bug Book: Foodborne pathogenic micro-organism and natural toxins handbook Staphylococcus aureus. 10903 New Hampshire Avenye Silver Spring, MD 20993.

25. WHO "World Health Organization" 2005. Fact sheet No. 139 (Revised April 2005). http:/www.who.intimediacentre/factsheetsl fsI39/en/pmt. html.

26. Yulistiani, R., Praseptiangga, D. and Supyani, S. 2019. Occurrences of Salmonella spp. and Escherichia coli in chicken meat, intestinal contents and rinse water at slaughtering place from traditional market in Surabaya, Indonesia. IOP Conf. Series: Materials Science and Engineering. doi:10.1088/1757-899X/633/1/012007. 